\title{
Multi-criteria approaches to identify the shoreline retreat downstream of dams: the North African case
}

\author{
Oula Amrouni ${ }^{1}$ and Gil Mahé ${ }^{2}$ \\ ${ }^{1}$ National Institute of Marine Sciences and Technologies, Laboratory of Marine Environment, \\ University of Carthage, Tunis, Tunisia \\ ${ }^{2}$ HSM, UMR 5151, CNRS, Université Montpellier, IRD, 300, Avenue du Professeur Emile Jeanbrau, \\ 34090 Montpellier, France \\ Correspondence: Oula Amrouni (oula.amrouni@instm.rnrt.tn) \\ Published: 16 November 2021
}

\begin{abstract}
Northern African beaches are among the most vulnerable areas under the extreme climate change hazard. Mainly sedimentary low-lying platform, the coasts are supplied by terrestrial yields, which are increasingly interrupted by dams. Unfortunately, the sediment fluxes are rarely measured and monitored, so that it is quite impossible today to assess the contribution of continental sediments to the coast and its variability. The aim of our study is to determine the sampling protocol of delta sedimentation plain and nearshore seabed for better understanding of the anthropogenic driver in contrast to climate change. We adopt a multi-criteria analysis based both on the geomorphologic feature and the historic evolution from the River to the littoral plain. The shoreline evolution reveals an alarming retreat trend reaching $-20 \mathrm{~m} \pm 0.15 \mathrm{~m} \mathrm{yr}^{-1}$ after the human-induced change where $\sim 50 \%$ of sediment discharge has been trapped upstream the dam, including quite all the coarse material, like sand. The shoreline retreat and the decreasing sediment rate of fluvial flow are all due to the dam construction.
\end{abstract}

\section{Introduction}

Deltaic coastal plains are among the most productive environment. It hosts complex and rich ecosystems such as wetlands, evaporate flats-sabkha- salt marsh and are a natural inlet barrier against the flood and storminess events. Modern-River system is defined by geologic settings with associated environmental processes (Coleman and Roberts, 1989). Mostly composed by sedimentary fine-grained landforms, deltaic coast are shaped, reworked and destructed by generated current-wave (Anthony, 2015). Beach equilibrium sediment balance depends on interactions between waves and fluvial discharge at the river mouth. Sediment discharge responds both to the impact of human activities and to changes in climate. Since the mid-century, human influences on the sediment flux to the coast have a significant effect on floodplain (Syvitski and Kettner, 2011), a large coastal land loss and delta-plain retrogradation (Benmoussa et al., 2018, 2019). Dams construction and maritime infrastructures have both intercepted the sediment supply and disturbed the sediment movements along the longshore path- ways. The Maghreb countries have launched since the 60s a vast program of dam's constructions to ensure the water supply for their developing populations and economies. Today the cumulated water storage capacity of the dams in Maghreb semi-arid region is of 28 billion cubic meters. But the dams also store large amounts of sediments. Unfortunately, the sediment fluxes are poorly monitored in most countries and thus it has been impossible up to now to quantify the amount of sediment that do not reach the sea anymore since the dams building. In the upcoming few decades, under the most plausible climatic and socio-economic scenario projection (SSP2-AVG), the North African countries will undergo water deficits ranging between $45 \%$ to $90 \%$ of their current water budget in 2050 (Mazzoni et al., 2018). Therefore, North African shoreline follows severe retreat trend since the last mid-century period and is perceived as vulnerable to the impacts of the natural hazard (Hzami et al., 2021). The main vulnerability drivers are rainfall fluctuation, sea level rise, and the increasing human impact. The combined climatic and human drivers will rapidly deteriorate the 
coastal aquifer, wetland ecosystem, agricultural, and tourism resources (Amrouni et al., 2019b).

This research aimed to identify the protocol and methods to determine how fluvial sediment discharge varies from source to sink, during the last modern-century under the increasing basin management constraint. This is helpful in understanding present trends in coastal regions, as well as attempting to predict future processes trends. It is worth saying that this type of research is developed in the 3 Maghreb countries, but is most advanced in Tunisia.

\section{Physiographic setting}

The study area is located in the North Africa coasts in the central Mediterranean - namely Maghreb - on the bay of the Gulf of Tunis, Tunisia. The littoral borders the low-lying upstream watershed of the Medjerda River plain. The Medjerda delta is located at $25 \mathrm{~km}$ northeast of Tunis capital city along the semi-arid central Mediterranean coast. The coast is about $35 \mathrm{~km}$ long and 20 to $200 \mathrm{~m}$ landward wide, microtidal ( $<2 \mathrm{~m}$ range), dissipative to intermediate and wavedominated types.

The delta valley is characterized by the evolution of several geomorphological entities (Fig. 1a). The sandy spit barrier, lagoons, sabkhas, salt marshes, dune ridge, subtidal bars and river meanders and channels across the coastal plain. The low-lying coastal plain of the Medjerda downstream valleys are filled by Pliocene and marine Quaternary deposits (El Arrim, 1996). The morphology of the embayed beaches is the result of a terrestrial filling coming from Medjerda River since the end of the Holocene transgression (Pleuger et al., 2019). The bay is bordered by two promontories, Cape Gammarth and Cape Ferina, which range in age from Pliocene and the Neotyrrhenian coastal deposits (Paskoff and Sanlaville, 1983). Based on the 1889 bathymetric map (scale $1: 334650$ ) for both the northern and central areas of the bay, nearshore setting reveals an irregular inner shelf bottom shape. In the northern ridge, the $10 \mathrm{~m}$ isobaths is $600 \mathrm{~m}$ far from the beach. In front of the old River mouth towards the North of the bay, it moves $3000 \mathrm{~m}$ from the coast. While in the central bay, in front of the new mouth of the Medjerda River, it gets closer by less than $1000 \mathrm{~m}$. The nearshore slope is steeper both in the Ferina and Gammarth Capes, where the $-6 \mathrm{~m}$ depth does not exceed $100 \mathrm{~m}$ from the shoreface (Fig. 1b).

The coast is dominated by the seasonal wind coming from the $\mathrm{N}$ to NE direction in Spring and Winter whereby storminess east to SE winds are responsible to the local incidentwave. Landward winds are blowing from the $\mathrm{W}$ to $\mathrm{NW}$ direction in Winter and sirocco winds from SW direction in summer season. The dominant longshore drift is from the NE to SE direction in Winter and Spring. A secondary SE/NW is generated during Summer from the eastern to southern winds. The average of significant wave height and period are $\sim 1.1 \mathrm{~m}$ and $8 \mathrm{~s}$ respectively (COADS, 1964). Maximum wave heights during high storms reached $\sim 5 \mathrm{~m}$ over the gulf of Tunis (INM, 2019). The relative sea level rise recorded in the Tunis Carthage tide-gauge station is about $+1.3 \mathrm{~mm} \mathrm{yr}^{-1}$ (Pirazzoli, 1986). The study area is under the temperate Mediterranean to semi-arid climate with rainfall in the northeastern region averaging 400 to $600 \mathrm{~mm} \mathrm{yr}^{-1}$ (INM, 2019). Rainfall pattern is highly variable, undergoing strong temporal and spatial fluctuations (Tramblay et al., 2013) with very high flood events, much reduced since the dams over the last 70 years with an average of $450 \mathrm{~mm}$ (Kotti et al., 2016).

The Medjerda River drains an area of $23600 \mathrm{~km}^{2}$. The average annual flow of $30 \mathrm{~m}^{3} \mathrm{~s}^{-1}$, which can reach $3500 \mathrm{~m}^{3} \mathrm{~s}^{-1}$ during exceptional extreme flood (Claude et al., 1977). Sediment load has been rarely studied, and a few recent data show a great variability from $50 \mathrm{~g} \mathrm{~L}^{-1}$ in 1989 to $10 \mathrm{~g} \mathrm{~L}^{-1}$ in 1990 (Soussi and Ben Mammou, 1989). The Medjerda River has formed the wetland system of the Gulf of Utica during the filling process since the last $\sim 1700$ years (Delile et al., 2015). In the study area, the most urbanized area over the country, 9 dams were built upstream of the Medjerda River and tributaries since 1954 totalizing a storage capacity of more than 1.4 billion cubic meters, including the largest dam of Sidi Salem which covers $75 \%$ of the surface of the basin (Fig. 1a) (Kotti et al., 2018a).

\section{Methodology}

The sediment yields into the Mediterranean Sea and their pattern are largely unknown. The scientific approach coupling continental and coastal investigation methods will help establish links between current attempts at quantifying and modeling them. They will be linked and calibrated with the sediment cores from floodplain areas, which will also help coastal environments researchers to better classify the vulnerability of coastal areas.

\subsection{Sedimentological analysis}

To determine the multi-decadal to pluri-annual sediment discharges from River downstream to coastal ridge we adopted a multi-criteria approach extended on the pre-estuarine areas of the Medjerda River new course artificially created since 1936. We propose first to analyze the sediment deposit fluctuations in regard of past events recorded on the inland basins lower Medjerda course in the floodplain, which is supposed to include effects of dam constructions, changes in agricultural practices and population density. Our second approach is based on the morphological evolution monitoring of the upstream basin including sandy and fine-grained beaches.

\subsubsection{Sediment sampling}

We collected 265 subsurface marine samples along the $20 \mathrm{~km}$ of the complex beaches covering the deltaic plain, lagoons, 


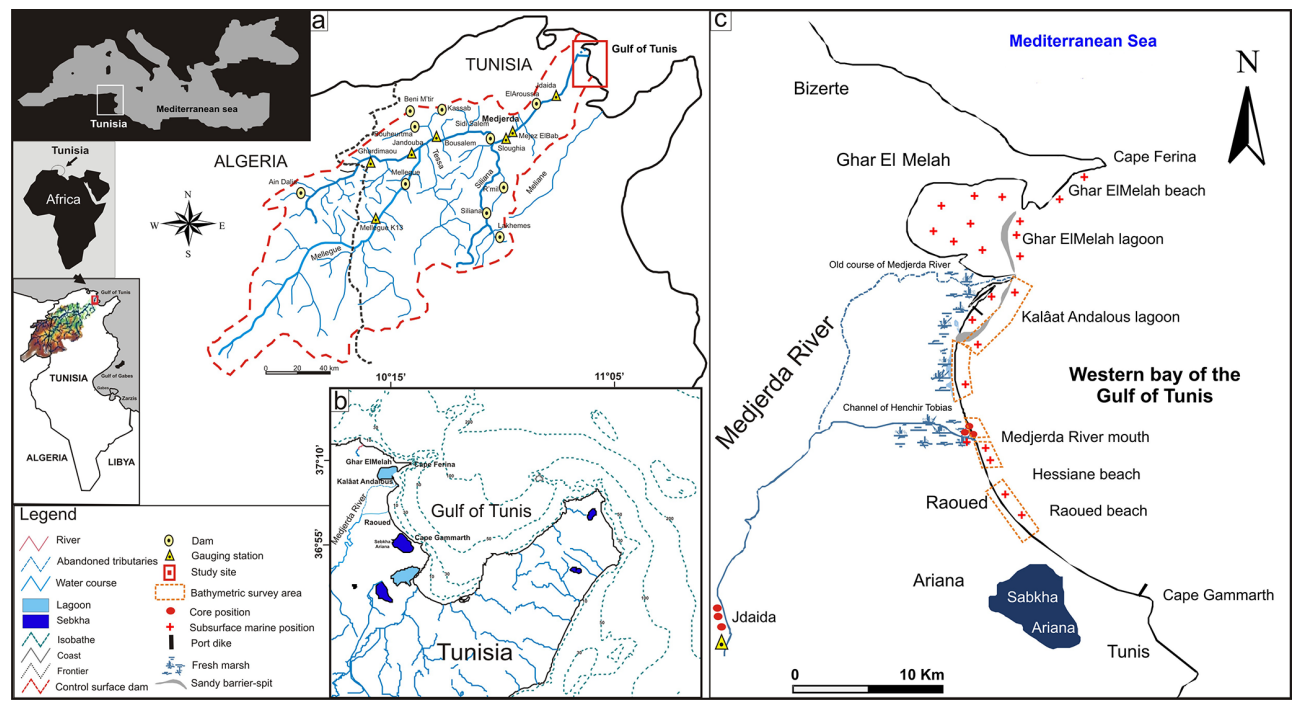

Figure 1. (a) Location map (from Kotti el al., 2018a) (b) Nearshore setting (c) Multi-criteria approaches methods in the Medjerda deltaic plain and coastal areas, Gulf of Tunis, Tunisia.

the sandy ridges, tidal inlets and the nearshore areas. For the medium to short temporal scales, field campaigns were organized seasonally and during the storm conditions. For the long-term monitoring, we collected 3 sediment cores between 0.42 to $1.68 \mathrm{~m}$ thickness in the pre-estuarine area, and 3 cores between 0.9 to $3 \mathrm{~m}$ thickness on terraces in the course of the river downstream of the last dams and far enough from the coast to avoid marine influence (Fig. 1c).

\subsubsection{Sediment analysis}

Collected sediments were undertaken particle-size distribution, by using classic indexes (average mean size $\mathrm{Mz}$ and/or median value Q2, Subsurface sorting index $\sigma$, asymmetry index SKI and kurtosis index KG), according to Folk and Ward (1957). The Malvern Mastersizer 2000 undertook the microgranulometric analysis for the measurement of particle size distributions within the range of 0.01-1000 microns. Modal statistical analysis are established from log-normal distribution and was determined to emphasize the percentage of the distribution of populations by grain-size (GSD) based on modal values in order to define the grain-size components and the sedimentary types to which they belong (Barusseau, 1973). Sediment Trend Analysis (STA) modeling tools according to the Le Roux approach (Le Roux, 1994) were applied to define the seasonal sediment transport pathways throughout the nearshore of the Medjerda delta.

\subsection{Photogrammetry and remote sensing}

In order to assess the long-term shoreline evolution, we perform time-series analysis of both photogrammetric Landsat, SPOT1, SPOT4 and sentinel 2A, 2B orbital scenes completed by the aerial photography, bathymetric and topographic maps dating from 1936-1948-1952-1974-1984-1988-1999 and 2016. The obtained datasets are analyzed using the ESRI ArcGIS 10.2.2 software to calculate shoreline evolution of change statistics from multiple coastline positions. Additionally, we use the Digital Shoreline Analysis System (DSAS) software to calculate the rate-of-change at the specified time interval (Thieler and Danforth, 1994). In our study area, transects were generated using DSAS every $\sim 1 \mathrm{~km}$ length with $\sim 200 \mathrm{~m}$ spacing to detect the high resolution changes (Hzami et al., 2018). DSAS tool provides a statistical calculation (Bush and Young, 2009) for each transect. The two statistical outputs calculated from the DSAS model are the Net Shoreline Movement (NSM), which provides the total reported separation between the oldest (1936) and current (2016) shoreline positions; and the End Point Rate (EPR), which is the annual rate of shoreline retreat.

\section{Results and discussions}

The present multi-criteria study reveals a complex sediment dynamic in the pre-estuarine and deltaic areas. We adopt multi-scale and regional approaches established by Cowell and Thom (1995) and Levoy (2000) to examine the beach sediment balance and the impact the anthropogenic factors on the littoral processes during the modern-decades.

\subsection{Sediment discharge evolution from River to coasts before dams}

In this study, sedimentological results reveal the dominance of two sediment types (ST): silt and clay type ST III (mean modal value Mo $<0.063 \mathrm{~mm}$ ) coming from the discontinuous supplies of rivers; and fine-grained sediment STI 


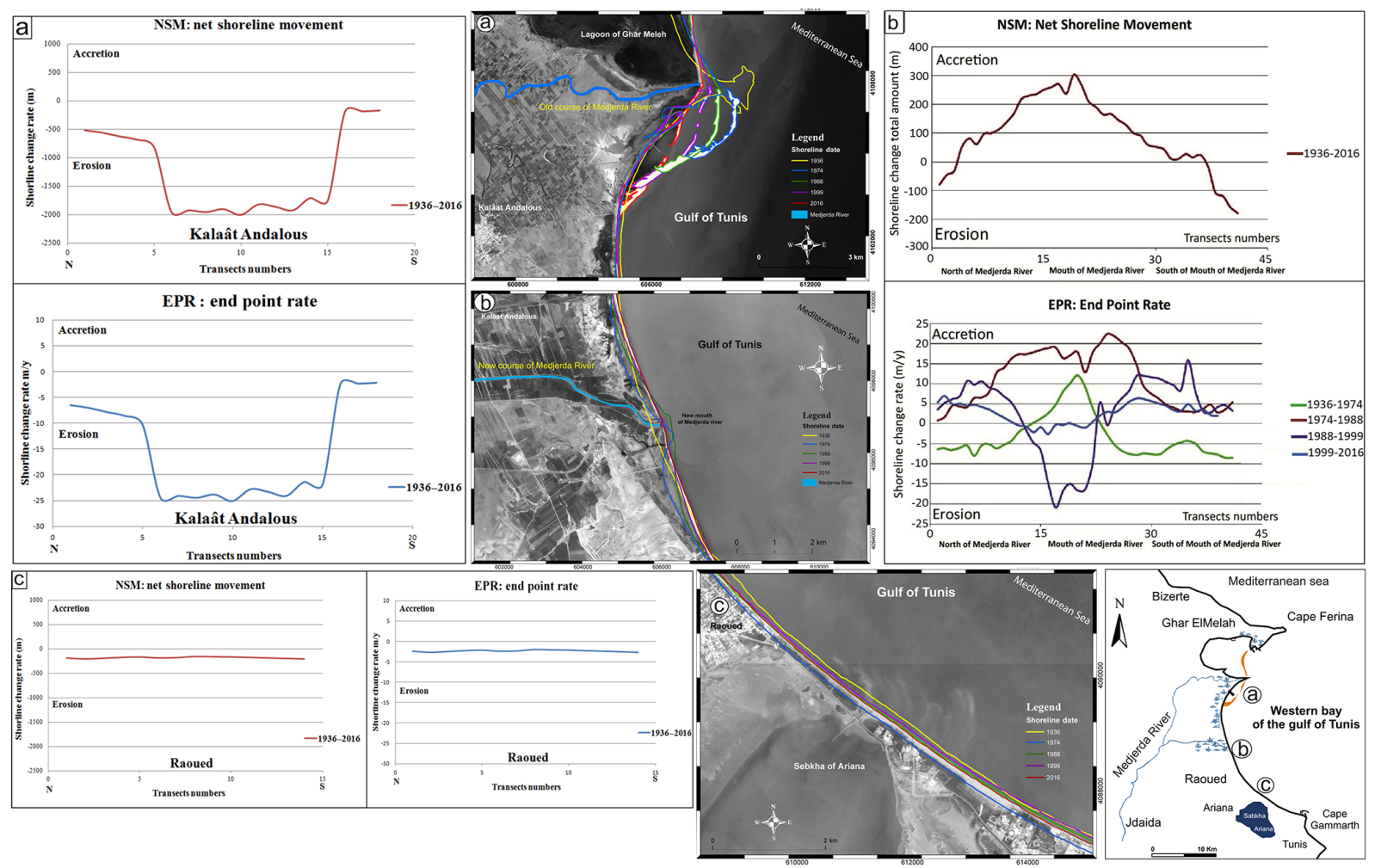

Figure 2. The diachronic shoreline evolution analysis at the deltaic and sandy beaches of the Gulf of Tunis, Tunisia. The Net Shoreline Movement (NSM) and The End-Point Rate (EPR) during the 1936-2016 period. The End-Point shoreline change Rates for the Gulf of Tunis beaches clearly show the erosion-dominated shoreline trend. Negative values indicate erosion. (C) Google Maps Software: Esri ArcGIS 10.2.

$(\mathrm{Mo}=0.125$ to $0.25 \mathrm{~mm})$ originating from the continuous reworking of erosion of the cliffs and coastal drift throughout beach during storm events. Seasonal sediment nearshore dynamic show that grain size distribution (GSD) and Sediment Trend Analysis (STA) model pathways are determined by cross-shore geomorphology, location of the sediment-cell, seasonal incident wave and local terrestrial supply (Amrouni et al., 2019a).

Longshore and short-term deltaic plain assessment reveals sedimentological spatial variability in both the pre-estuarine and nearshore areas. In early century, the natural progression between 1936 to 1952 is marked by the deltaic plain progradation of the Medjerda River with a fluvial sedimentary unit mainly composed by silt and clay deposits rich in terrigenous components $(\mathrm{D} 50=98 \mu \mathrm{m})$ (Benmoussa et al., 2018). The shoreline evolution shows a net accretion rate during this period with a positive rate of change NSM by $+300 \mathrm{~m} \pm 25 \mathrm{~m}$. The flood event occurred in 1973 is marked by the dissymmetric morphology of the mouth River clearly observed on aerial photography of 1974 dataset (Fig. 2a). The shoreline level shows accretion rate at the mouth of the new artificial channel, from 1952 to 1981 with an EPR average of $+13 \mathrm{~m} \pm 0.15 \mathrm{~m} \mathrm{yr}^{-1}$. Geomorphological dissymmetry observed on the multi-temporal scenes of 1973 is the re- sponse of the reworking of the tidal-inlet by the wave action during storm surge.

\subsection{Sediment discharge evolution from River to coasts after dams}

After the dam construction, by the 1980th both the deltaic plain and the nearshore seabed are marked by decreasing of the grain size distribution with a clay deposit facies $(\mathrm{D} 50=60 \mu \mathrm{m})$. The temporal evolution shows a rapid recession of the delta plain and shoreline level (Kotti et al., 2018b; Benmoussa et al., 2019). The dominance of clay deposits more than coarser fraction results from the impact of the construction of several large dams on the basin. Only the finer grain size fractions can feed the coast as revealed by the analysis of several cores in the lower alluvial plain of the Medjerda before the sea with Cesium, granulometry and geochemistry, coupled with the hydrological proxy (Kotti et al., 2018a).

The long term shoreline evolution between the periods 1974-1984 and 1988 shows a severe beach erosion trend extended in the entire delta shoreline with an EPR range of $-20 \pm 0.15 \mathrm{~m} \mathrm{yr}^{-1}$ and a maximum NSM rate of $-219 \mathrm{~m} \pm 2 \mathrm{~m}$. Currently, the sediment balance of the gulf of Tunis coast shows an extended shoreline retreat under the 


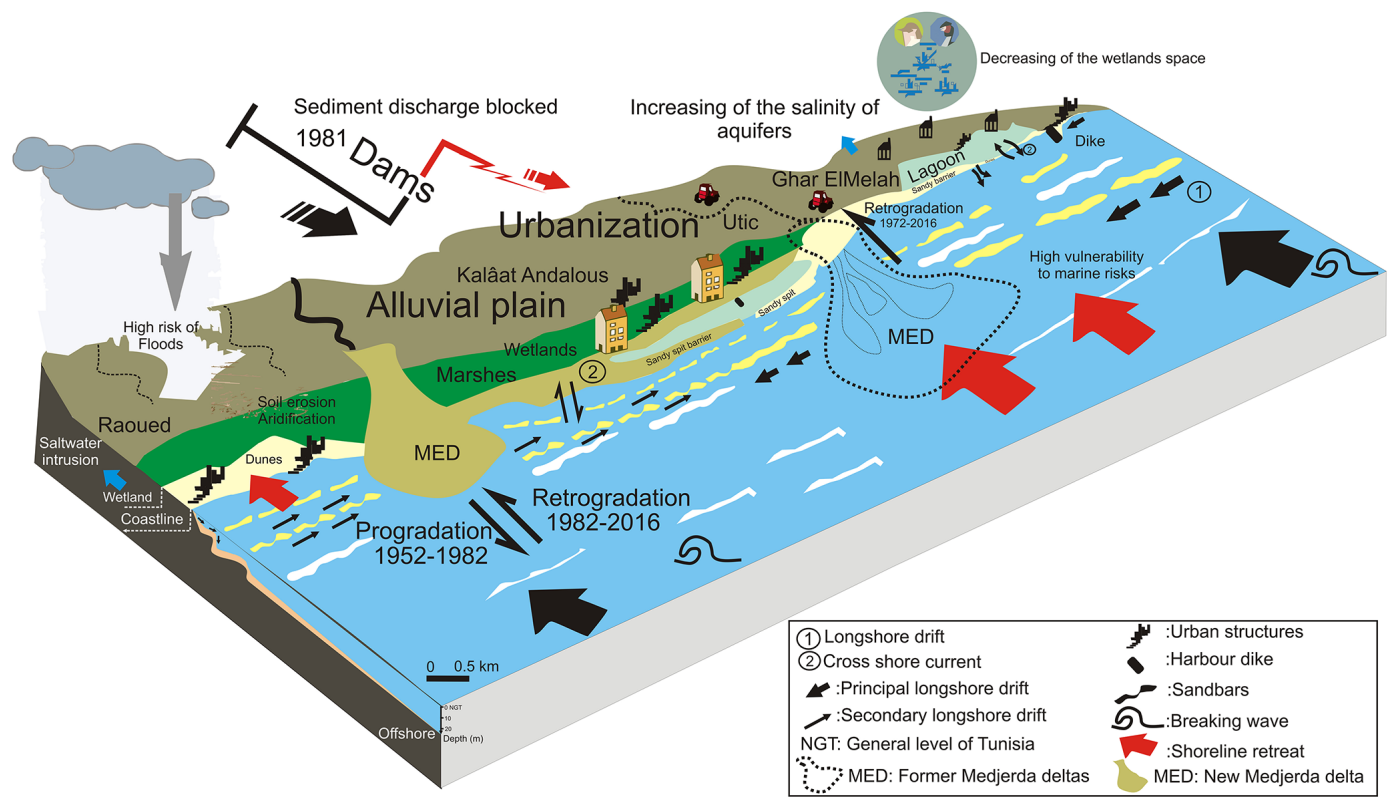

Figure 3. Environmental implication of the dam infrastructure on North African coasts ecosystems.

coarser sediment deficit, as at least $50 \%$ of sediments no more reach the sea and are blocked by upstream dams. The old estuarine plain and delta mouth is experiencing a "hot spot" sediment loss with a Maximum Net Shoreline movement (NSM) of $-1570 \mathrm{~m} \pm 6 \mathrm{~m}$ inland between the period 1936 to 2016 (Fig. 2a). The progradation and retrogradation of the Medjerda Delta plain during the last century is strongly influenced by anthropogenic factor. Sediment deposit facies associated to geomorphological evolution of post-dam alluvial deposits confirms the shoreline retreat due to continental sediment reduction. Even though the southward beach shoreline seems not to be threatened by the deltaic regression (Fig. 2c), the beach stability is closely sensitive to rapid urban expansion, the dam construction and the overexploitation of natural resources over the entire river basin (i.e, coastal aquifer, wetland, sabkhas, etc.) (Fig. 3).

\section{Conclusions}

Our multi-criteria approach results confirm that the construction of dams greatly modify the quantity and the quality of the sediments downstream of dams to the sea. In the case of deltaic system of the Medjerda River, extended in semiarid areas, deltaic plain is marked by the loss of sediments discharge that no more reach the sea, and the absence of coarse particle-size in recent decades cores sediment. Our study reveals an alarming shoreline retreat trend reaching $-20 \mathrm{~m} \pm 0.15 \mathrm{~m} \mathrm{yr}^{-1}$ after the human-induced change where $\sim 50 \%$ of sediment discharge has been trapped upstream the dam.

Thus, since the last decades, no more sand reaches the sea from the largest river in North African network into the Mediterranean Sea. Anthropogenic infrastructures have a great impact on coastal areas evolution such as the severe shoreline retreat associated to a large sandy beach-loss of $-1570 \mathrm{~m} \pm 6 \mathrm{~m}$ inland over the study period (1936 to 2016), alarming reduction of the deltaic plain and wetland areas, and changes in the ecohydrology balance, with impacts on the socio-economic activities. This coastal issue is superimposed to the beach vulnerability due to the marine hazard and climate changes disasters.

Code availability. The licence of the software code Esri ArcGIS 10.2 is provided by the Hydroscience of Montpellier Research website (HSM, Montpellier) (https://app.umontpellier.fr/securum/public/centralAuthentication, last access: 19 October 2021).

Data availability. Data set related to the physical parameters of the wave propagation are provided by the database of COADS (1964) (https://shen.sdsu.edu/researchgroup/coads.htm, last access: 20 October 2021).

Author contributions. OA and GM conceived the scientific project PHC-UTIQUE-RYSCMED 16G1005 (2016-2018) and the research monitoring and wrote the manuscript. OA coordinate and supervised the Tunisian-French workfield compaigns. GM supported the software acquirement and model development. Both OA and GM edited the paper and provided comments. 
Competing interests. The contact author has declared that neither they nor their co-authors have any competing interests.

Disclaimer. Publisher's note: Copernicus Publications remains neutral with regard to jurisdictional claims in published maps and institutional affiliations.

Special issue statement. This article is part of the special issue "Hydrology of Large River Basins of Africa". It is a result of the 4th International Conference on the "Hydrology of the Great Rivers of Africa", Cotonou, Benin, 13-20 November 2021.

Acknowledgements. The authors are grateful to all the research members who contributed to the scientific and academic tasks during the project. The authors would also like to thank the Copernicus editorial support team for their editing that helped improve this manuscript.

Financial support. This research has been funded by the National Institute of Marine Sciences and Technologies in Tunisia, University of Carthage. This project was developed under the framework of the PHC-UTIQUE-RYSCMED (grant nos. 16G1005 and 34854QC) project and the institutional DYNAMISME \& MOSBIOCLIM research projects funded by the Tunisian High Ministry of Education and Scientific Research and Campus France.

\section{References}

Amrouni, O., Sánchez, A., Khélifi, N., Benmoussa, T., Chiarella D., Mahé G., Abdeljaouad S., and McLaren P.: Sensitivity assessment of the deltaic coast of Medjerda based on fine-grained sediment dynamics, Gulf of Tunis, Western Mediterranean, J. Coast. Conserv., 23, 571-587, https://doi.org/10.1007/s11852019-00687-x, 2019a.

Amrouni, O., Hzami, A., and Heggy, E.: Photogrammetric assessment of shoreline retreat in North Africa: anthropogenic and natural drivers, ISPRS J. Photogramm., 157, 73-92, https://doi.org/10.1016/j.isprsjprs.2019.09.001, 2019b.

Anthony, E. J.: Wave influence in the construction, shaping and destruction of river deltas: A review, Mar. Geol., 361, 53-78, https://doi.org/10.1016/j.margeo.2014.12.004, 2015.

Barusseau, J. P.: Evolution du plateau continental rochelais (golfe de Gascogne) au cours du Pléistocène terminal et de l'Holocène. Les processus actuels de la sédimentation, Thèse Es-Science, Université de Bordeaux I, Bordeaux, France, 360 pp., 1973.

Benmoussa, T., Amrouni, O., Dezileau, L., Mahé, G., and Abdeljaouad, S.: The sedimentological changes caused by human impact at the artificial channel of Medjerda-River (Coastal zone of Medjerda, Tunisia), Proc. IAHS, 377, 77-81, https://doi.org/10.5194/piahs-377-77-2018, 2018.

Benmoussa, T., Amrouni, O., Hzami, A., Dezileau, L., Mahe, G., Condomines M., and Saadi A.: Progradation and retrogradation of the Medjerda delta during the 20th century (Tunisia, Western
Mediterranean), Comptes Rendus Geosciences, 351, 340-350, 2019.

Bush, D. M., and Young, R.: Coastal features and processes, in: Geological Monitoring, edited by: Young, R. and Norby, L., Geological Society of America, Boulder Colorado, pp. 47-67, available at: https://www.nps.gov/articles/ geological-monitoring-of-coastal-features-and-processes.htm (last access: 19 October 2021), 2009.

Claude, J., Francillon, G., and Loyer, J. Y.: Les alluvions déposées par l'Oued Medjerda lors de la crue exceptionnelle de mars 1973. Cahiers ORSTOM, Ser. Hydrol. 14, 37e109, available at: http://horizon.documentation.ird.fr/exl-doc/pleins_ textes/divers14-05/08532.pdf (last access: 19 October 2021), 1977.

COADS: Comprehensive Ocean-Atmosphere Data Set, Release 1, NOAA Environmental Research Laboratories [data set], Climate Research Program, Boulder, CO, 268 pp., available at: https: //shen.sdsu.edu/researchgroup/coads.htm (last access: 19 October 2021), 1964.

Coleman, J. M. and Roberts, H. H.: Deltaic coastal wetlands, in: Coastal Lowlands, edited by: van der Linden, W. J. M., Cloetingh, S. A. P. L., Kaasschieter, J. P. K., van de Graaff, W. J. E., Vandenberghe, J., and van der Gun, J. A. M., Springer, Dordrecht, the Netherlands, 1989.

Cowell, P. and Thom, B.: Morphodynamics of coastal evolution, in: Coastal Evolution: Late Quaternary Shoreline Morphodynamics, edited by: Plassche, O., Carter, R., and Woodroffe, C., Cambridge University Press, Cambridge, UK, pp. 33-86, https://doi.org/10.1017/CBO9780511564420.004, 1995.

Delile, H., Abichou, A., Gadhoum, A., Goiran, J. P., Pleuger, E., Monchambert, J. Y., Wilson, A., Fentress, E., Quinn, J., Ben Jerbania, I., and Ghozzi, F.: The Geoarchaeology of Utica, Tunisia: the paleogeography of the Mejerda Delta and hypotheses concerning the location of the Ancient Harbor, Geoarchaeology, 30, 291-306, https://doi.org/10.1002/gea.21514, 2015.

El Arrim, A.: Étude d'impact de la dynamique sédimentaire sur la stabilité du littoral du Golfe de Tunis, Doctorat de spécialité, Unversité de Tunis El Manar, Tunis, Tunisia, 203 pp., 1996.

Folk, R. L. and Ward, W. C.: Brazos river bar: a study in the signification of grain size parameters, J. Sediment. Petrol., 27, 3-26, 1957.

Hzami, A., Amrouni, O., Romanescu, G., Constantin Stoleriu, C., Mihu-Pintilie, A., and Saâdi, A.: Satellite images survey for the identification of the coastal sedimentary system changes and associated vulnerability along the western bay of the Gulf of Tunis (northern Africa), Proc. IAHS, 377, 83-89, https://doi.org/10.5194/piahs-377-83-2018, 2018.

Hzami, A., Heggy, E., Amrouni, O., Mahe, G., Manaan, M., and Abdeljaouad, S.: Alarming coastal vulnerability of the deltaic and sandy beaches of North Africa, Sci. Rep., 11, 2320, https://doi.org/10.1038/s41598-020-77926-x, 2021.

INM: Tunisian National Institute of Meteorology, INM, Data-base, available at: http://www.meteo.tn/htmlfr/accueil.php (last access: 19 October 2021), 2019.

Kotti, F., Mahe, G., Habaieb, H., Dieulin, C., and Calvez, R.: Etude des pluies et des débits sur le bassin versant de la Medjerda, Tunisie, Bulletin de l'Institut Scientifique, 38, 19-28, 2016.

Kotti, F., Dezileau, L., Mahe, G., Habaieb, H., Benabdallah, S., Bentkaya, M., Calvez, R., and Dieulin, C.: The im- 
pact of dams and climate on the evolution of the sediment loads to the sea by the Medjerda River using a paleohydrological approach, J. Afr. Earth Sci., 142, 226-233, https://doi.org/10.1016/j.jafrearsci.2017.10.003, 2018a.

Kotti, F., Dezileau, L., Mahé, G., Habaieb, H., Bentkaya, M., Dieulin, C., and Amrouni, O.: Etude de l'impact des barrages sur la réduction des transports sédimentaires jusqu'à la mer par approche paléohydrologique dans la basse vallée de la Medjerda, Proc. IAHS, 377, 67-76, https://doi.org/10.5194/piahs-377-672018, 2018b.

Le Roux, J. P.: An alternative approach to the identification of the end sediment transport paths based on grain size trends, Sediment. Geol., 94, 97-107, 1994.

Levoy, F.: Morphodynamique des plages sableuses et trait de côte à différentes échelles spatio-temporelles, vol. I., Mémoire d'habilitation, UFR des Sciences de la Terre et de l'Aménagement Régional, Université de Caen BasseNormandie, Caen, France, 150 pp., 2000.

Mazzoni, A, Heggy, E., and Scabbia, G.: Forecasting water budget deficits and groundwater depletion in the main fossil aquifer systems in North Africa and the Arabian Peninsula, Global Environmental Change, 53, 157-173, 2018.

Paskoff, R. and Sanlaville, P.: Les côtes de la Tunisie. Variations du niveau marin depuis le Tyrrhénien, Coll. Maison Orient Medit., 14, Sér. Géogr. et Préhist., 192 pp., available at: https://www. persee.fr/issue/mom_0243-2439_1983_mon_14_1 (last access: 19 October 2021), 1983.
Pirazzoli, P. A.: Secular trends of relative sea level (RSL) changes indicated by tide-gauge records, J. Coastal Res., 1, 1-26, available at: http://www.jstor.org/stable/44863318 (last access: 19 October 2021), 1986.

Pleuger, E., Goiran, J.-P., Mazzini, I., Delile, H. Abichou, A., Gadhoum, A., Djerbi, H., Piotrowska, N., Wilson, A., Fentress, E. Ben Jerbania, I., and Fagel, N.: Paleogeographical and paleoenvirenmental reconstitution of the Medjerda delta (Tunisia) during the Holocene, Quaternary Sci. Rev., 220, 263-178, 2019.

Soussi, N. and BenMammou, A.: Les apports solides en suspension de la Medjerda-Tunisie, 2ème congrès de sédimentologie, Paris, 1989.

Syvitski, P. M. and Kettner, A.: Sediment flux and the Anthropocene, Phil. Trans. R. Soc. A, 369, 957e975, available at: https: //www.jstor.org/stable/41061709 (last access: 19 October 2021), 2011.

Thieler, E. R. and Danforth, W.: Historical Shoreline Mapping (II): Application of the Digital Shoreline Mapping and Analysis System (DSMS/DSAS) to Shoreline Change Mapping in Puerto Rico, J. Coastal Res., 10, 600-620, available at: https: //pubs.er.usgs.gov/publication/70135638 (last access: 19 October 2021), 1994.

Tramblay, Y., El Adlouni, S., and Servat, E.: Trends and variability in extreme precipitation indices over Maghreb countries, Nat. Hazards Earth Syst. Sci., 13, 3235-3248, https://doi.org/10.5194/nhess-13-3235-2013, 2013. 